УДК 631.48

DOI: $10.18101 / 2542-0623-2019-3-62-73$

\title{
ФТОР В ВОДАХ И ПОЧВАХ УЛЮНХАНСКОЙ ВПАДИНЫ (БАЙКАЛЬСКАЯ РИФТОВАЯ ЗОНА)
}

\author{
А. Д. Жамбалова \\ (C) Жамбалова Анна Дашиевна \\ кандидат биологических наук, \\ Институт общей и экспериментальной биологии СО РАН \\ Россия, 670047, г. Улан-Удэ, ул. Сахьяновой, 6 \\ E-mail: zhambalova ann@mail.ru
}

Представлены первичные данные по активности фтора в засоленных почвах зон тектонических разломов Улюнханской впадины (северо-западная часть Баргузинской котловины). Выявлено, что активность ионов фтора колеблется в очень широком диапазоне от 0,02 до 112,20 ммоль/л. Высокая активность ионов F в основном представлена на испарительном барьере. В поверхностных солевых корках отмечаются аномально высокие показатели. Внутри профиля почв активность фтора зависит от реакции среды. Самые низкие значения $\mathrm{aF}$ приурочены к почвам болотного массива с кислой реакцией. Увеличение $\mathrm{aF}$ в почвах аллювиальной возвышенности происходит в горизонтах с более щелочными условиями. Привнос ионов фтора происходит за счет скрытой внутрипрофильной газогидротермальной деятельности кучигерских источников, которая осуществляется по тектоническим трещинам и разломам и имеет пульсирующий характер.

Ключевые слова: Баргузинская котловина; засоленные почвы; активность фтора; почвы зон разломов; геохимический барьер.

\section{Для цитирования}

Жамбалова А. Д. Фтор в водах и почвах Улюнханской впадины (Байкальская рифтовая зона) // Природа Внутренней Азии. Nature of Inner Asia. 2019. № 3(12). С. 62-73. DOI: 10.18101/2542-0623-2019-3-62-73

\section{Введение}

Байкальская рифтовая зона характеризуется многочисленным выходом гидротермальных минерализованных вод разного химического и газового состава [Плюснин и др., 2013]. Основные гидротермы северо-западной части рифтовой зоны сконцентрированы в одной из самых крупных впадин - Баргузинской. В северной части котловины разгружаются гидротермы, по химическому составу относящиеся к фторидному гидрокарбонатно-сульфатно-натриевому, так называемому Кульдурскому, типу с высоким содержанием натрия, серы, фтора и кремния. Большинство элементов, разгружающихся в почву, оседают на геохимических барьерах и создают специфические геохимические ассоциации [Касимов, 1980]. Высокое содержание ионов натрия и сульфатов в водах источника обусловило их накопление и в прилегающих почвах [Жамбалова, 2018]. 
Особый интерес вызывает изучение фтора, наиболее токсичного элемента, имеющего высокое содержание в водах гидротерм. Фтор относится к первому классу опасности [Фомин Г., Фомин А., 2001] и, кроме того, является одним из необходимых элементов, который участвует в образовании твердых тканей организма [Авцын и др., 1991]. Нарушение обмена фтора в организме приводит к заболеванию зубов и костных тканей. При его недостатке снижается устойчивость зубной эмали, вследствие чего происходит разрушение зубов (кариес). Характерным заболеванием при избыточном поступлении фтора в организм является флюороз, а также происходит поражение зубов, скелета, развиваются остеопороз и гастрит [Конарбаева, 2004]. Для растительного сообщества повышенное содержание фтора оказывает токсичное действие, так как ингибируется активность целого ряда ферментов, принимающих участие в углеводно-фосфорном обмене, тканевом дыхании [Школьник, 1974; Kabata-Pendias, 2011].

В биосфере круговорот F тесно связан с вулканизмом [Перельман, Касимов, 1999]. При вулканических извержениях выделяется фтористый водород. В таких ландшафтах содержание фтора избыточно, им обогащены воды (>1 мг/л), что сопровождается заболеванием костной системы (флюорозом). На миграцию фтора влияют щелочно-кислые условия, сорбенты, фосфатные и кальциевые геохимические барьеры. Подщелачивание среды до рН6-7 способствует его адсорбции минеральными компонентами почвы [Перельман, Касимов, 1999].

Источники поступления фтора в природные воды: фтористые минералы, водовмещающие породы, в которых фтор находится в рассеянном состоянии, вулканические эксгаляции. Самые высокие концентрации фтора отмечены в минеральных источниках сульфатно-карбонатно-натриевого типа, образование которых связано с вулканической деятельностью [Аничкина, 2016].

Азотные термальные минеральные источники Забайкалья богаты фтором [Замана, 2000; Плюснин и др., 2013 и др.]. Динамически равновесная система, сформированная в условиях дефицита кислот при $\mathrm{pH}$ до 9-10, определяет относительно быстрое осаждение карбонатных минералов и обеспечивает низкое содержание $\mathrm{Ca}, \mathrm{Mg}, \mathrm{Fe}$ и других элементов в азотных термах, что способствует накоплению в них фтора [Шварцев, 2017].

Учитывая высокую токсичность фтора и его постоянное поступление в почвы, целью работы явилось изучение активности ионов фтора в засоленных почвах зон тектонических разломов азотных терм Кучигерского источника. В последнее время параметры активности ионов в почве учитываются при расчете химических равновесий в математическом моделировании почвенных процессов и при оценке влияния различных ионов и солей на растения. Показатель активности дает важную информацию о состоянии компонента в растворе и его возможности вступать во взаимодействие с другими компонентами в растворе, твердой фазе, почвенном поглощающем комплексе (ППК), в растениях [Хитров, 1990].

\section{Объекты и методика исследования}

Исследования проводились в северной части Баргузинской котловины в пределах Улюнханской впадины. Для нее характерна разгрузка кучигерских гидротер- 
мальных источников. Выклинивание минерализованных вод приурочено к пересечению самого крупного разлома котловины - Баргузинского с более мелким поперечным Дыренским. В настоящее время на территории впадины регистрируются тектоническая активность и максимальный тепловой поток [Лысак, 2002; Лунина и др., 2009; Чернявский и др., 2018, В Бурятии... 2019].

Вода источника - сильно-щелочная (pH 9,28-9,90), минерализация 365508 мг/дм³ ${ }^{3}$ хлоридно-сульфатно-фторидно-гидрокарбонатная натриевая [Чернявский и др., 2018]. Формула Курлова имеет вид:

$$
\mathrm{M} 0,39 \frac{\mathrm{HCO}_{3} 41 \mathrm{~F} 25 \mathrm{SO}_{4} 19 \mathrm{Cl} 11}{\mathrm{Na} 95} \mathrm{pH} 9,6 \mathrm{~T} 34 .
$$

Объектами изучения послужили почвы нескольких ключевых участков почвенно-геоморфологической катены РФ-2, протянутой вдоль переходной полосы от болота к аллювиальной равнине р. Индэхэн (табл. 1).

Таблица 1

Географическое положение почв почвенно-геоморфологической трансекты РФ-2

\begin{tabular}{|c|c|c|}
\hline № разреза & Координаты & Высота над ур.м. \\
\hline РФ-2-11 & $\mathrm{N} 54^{\circ} 52^{\prime} 45,8 » ; \mathrm{E} 111^{\circ} 00^{\prime} 1,2 »$ & 564 \\
\hline РФ-2-13 & $\mathrm{N} 54^{\circ} 52^{\prime} 45,3 » ; \mathrm{E} 111^{\circ} 00^{\prime} 0,3 »$ & 564 \\
\hline РФ-2-15 & 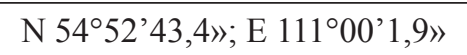 & 566 \\
\hline РФ-2-16 & 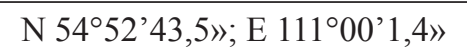 & 566 \\
\hline РФ-2-17 & $\mathrm{N} 54^{\circ} 52^{\prime} 43,3 » ; \mathrm{E} 111^{\circ} 00^{\prime} 2,2 »$ & 564 \\
\hline РФ-2-18 & 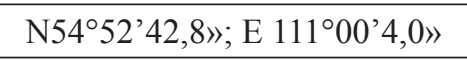 & 561 \\
\hline РФ-2-19 & $\mathrm{N} 54^{\circ} 52^{\prime} 42,4 » ;$ E $111^{\circ} 00^{\prime} 6,0 »$ & 560 \\
\hline РФ-2-20 & $\mathrm{N}_{5} 4^{\circ} 52^{\prime} 42,5 » ; \mathrm{E} 111^{\circ} 00^{\prime} 6,2 »$ & 555 \\
\hline РФ-2-21 & $\mathrm{N} 54^{\circ} 52^{\prime} 42,5 » ;$ E $111^{\circ} 00^{\prime} 6,0 »$ & 564 \\
\hline РФ-2-23 & $\mathrm{N} 54^{\circ} 52^{\prime} 42,1 » ; \mathrm{E} 111^{\circ} 00^{\prime} 7,2 »$ & 560 \\
\hline РФ-2-24 & 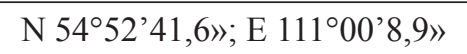 & 564 \\
\hline PФ-2-25 & N 5452’42,2»; E $111^{\circ} 00^{\prime} 1,9 » »$ & 563 \\
\hline РФ-2-26 & 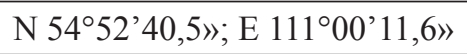 & 565 \\
\hline РФ-2-27 & 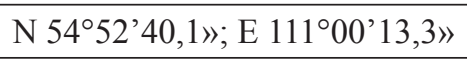 & 565 \\
\hline РФ-2-28 & $\mathrm{N} 54^{\circ} 52^{\prime} 39,2 » ; \mathrm{E} 111^{\circ} 00^{\prime} 15,2 »$ & 564 \\
\hline РФ-2-29 & 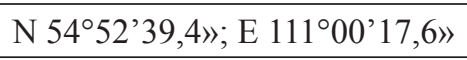 & 562 \\
\hline РФ-2-30 & 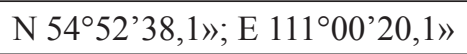 & 562 \\
\hline РФ-2-31 & 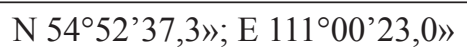 & 570 \\
\hline
\end{tabular}

Классификация и диагностика почв проводились согласно положениям «Классификация и диагностика почв России» [2004] и «Полевого определителя почв России» [2008]. Определены актуальная кислотность $\left(\mathrm{pH}_{\text {вод }}\right)$, содержание органи- 
ческого углерода методом И. В. Тюрина; гранулометрический состав по Качинскому [Аринушкина, 1970; Агрохимические... 1975]. Содержание легкорастворимых солей в водной вытяжке 1:5. Степень засоления определяли в зависимости от его химизма [Засоленные... 2006]. Активность ионов фтора определялась с помощью ионселективного фторидного электрода в почвенной пасте [Хитров, 1990]. Статистическая обработка данных включала расчет основных показателей в пакетах Statistica 10 и Microsoft Excel 2010.

\section{Результаты и обсуждения}

Реки и подземные воды изученной территории характеризуются очень низким содержанием фтора. Согласно ГОСТу 2874-82, концентрация фтора в питьевой воде должна быть $0,5-1,5$ мг/л, а в Баргузинской котловине содержание этого элемента в 2 раза ниже уровня, предъявляемого для питьевой воды по СанПину 2.1.4.1116-02 (рис. 1) [Кашин и др., 2015].

В водах Кучигерского источника содержание фтора в разные годы колеблется от 13,9 в 2015 г до 62,7 мг/дм³ в 2014 г. [Чернявский и др., 2018] (рис. 1). Поступление такого высокого количества ионов фтора в почву из гидротерм приводит к его накоплению.

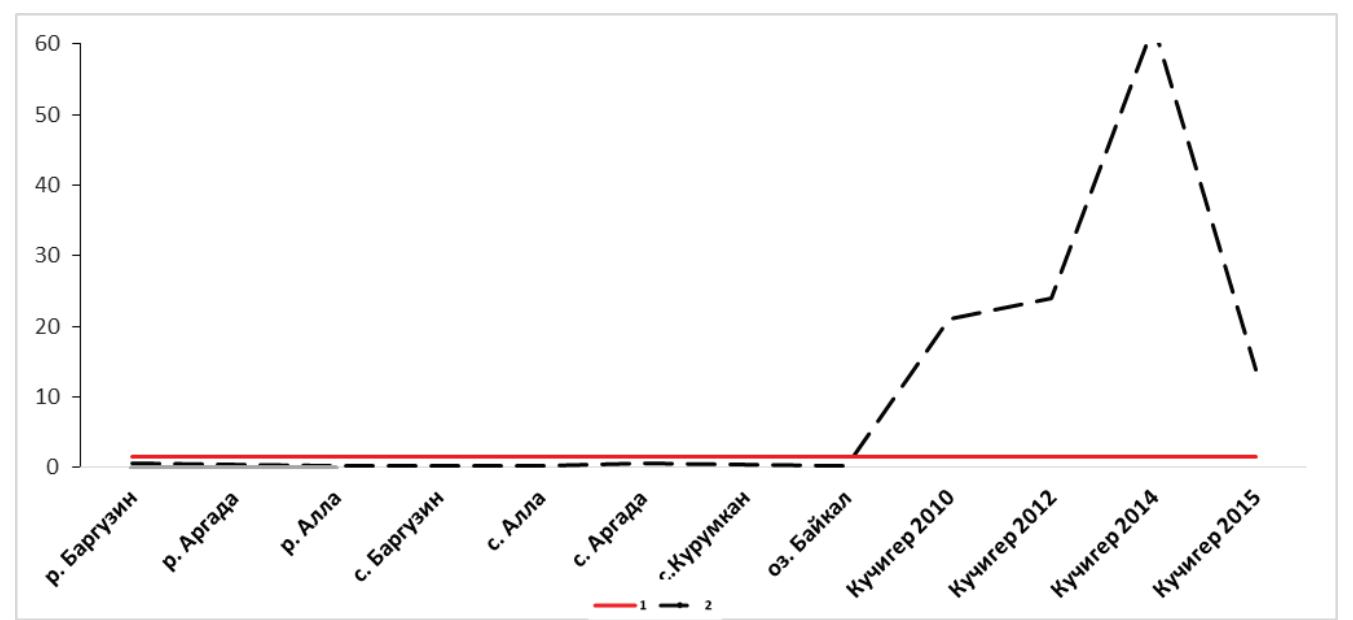

Рис. 1. Содержание фтора в водах рек и подземных вод (скважины и колодцы населенных пунктов) северной части Баргузинской котловины [Кашин и др., 2015; Чернявский и др., 2018]. Условные обозначения: 1 - норма по СанПину; 2 - содержание в водах Баргузинской котловине

Изученные засоленные почвы приурочены к зоне скрытого влияния Кучигерского источника. На исследуемой территории не зафиксировано открытой разгрузки минеральных грифонов, но по морфологическому, вещественному и составу легкорастворимых солей почвы генетически сопряжены с почвами, сформированными в непосредственной близости от источников [Жамбалова, 2018; Убугунов и др., 2018]. Профиль изученных почв сильно обводнен и на разных глубинах зафиксировано проявление теплых грунтовых вод.

Проведенные исследования показали, что активность фтора изменяется от 0 до 100 ммоль/л и большинстве изученных почв находится в пределах $0,42-0,59$ ммоль/л. При выборке $\mathrm{n}=102$ среднее значение $\mathrm{aF}$ составляет 0,50 ммоль/л. 
Реакция среды в изученных почвах изменяется от кислой до сильнощелочной (табл. 2). Кислая реакция почвенного раствора характерна для почв, сформированных в болотном массиве (РФ-2-11, РФ-2-13). Отмечается резкая смена рН среды не только в отдельных разрезах, но и в самом почвенном профиле. Все почвы в разной степени засолены (табл. 2).

Таблийа 2

Некоторые физико-химические свойства почв с низкой активностью фтора $\mathrm{aF}$

\begin{tabular}{|c|c|c|c|c|c|c|}
\hline \multirow[t]{2}{*}{ Разрезы } & \multirow[t]{2}{*}{ Глубина } & \multirow{2}{*}{$\mathrm{pH}_{\text {водн }}$} & $\mathrm{CO}_{2}$ & Гумус & $\begin{array}{c}\text { Сухой } \\
\text { остаток }\end{array}$ & $\begin{array}{c}\text { Сод. фракции } \\
<0,01\end{array}$ \\
\hline & & & \multicolumn{4}{|c|}{$\%$} \\
\hline \multirow{7}{*}{ РФ-2-11 } & Солевая корка & 4,9 & \multicolumn{4}{|c|}{ не опр. } \\
\hline & $0,5-5$ & 4,8 & - & 13,36 & 3,788 & не опр. \\
\hline & $5-20$ & 4,9 & 0,19 & 10,17 & 0,522 & 33 \\
\hline & $20-35$ & 4,7 & 0,09 & 6,36 & 0,678 & 34 \\
\hline & $35-50$ & 4,8 & - & 9,18 & 0,382 & 35 \\
\hline & $50(55)-60$ & 4,4 & 0,56 & 0,43 & 0,170 & 3 \\
\hline & 70-78 & 4,5 & 0,56 & 0,77 & 0,484 & 9 \\
\hline \multirow{4}{*}{ РФ-2-13 } & $0-6$ & 5,0 & - & 10,08 & 0,370 & не опр. \\
\hline & $6-30$ & 5,1 & 0,19 & $22,30^{*}$ & 0,792 & 45 \\
\hline & $30-50$ & 4,7 & - & 7,32 & 0,806 & 70 \\
\hline & $50-90$ & 6,8 & 0,09 & 6,24 & 0,776 & 57 \\
\hline \multirow{6}{*}{ РФ-2-16 } & Солевая корка & 4,7 & не опр. & 1,21 & 0,950 & не опр. \\
\hline & $0-7$ & 6,1 & - & 0,31 & 0,198 & 8 \\
\hline & $7-13$ & 5,9 & 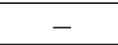 & 0,32 & 0,178 & 7 \\
\hline & $13-20$ & 5,4 & - & 0,50 & 0,280 & 8 \\
\hline & $20-40$ & 5,1 & - & 0,86 & 0,420 & 8 \\
\hline & $40-65$ & 5,2 & - & 0,24 & 0,742 & 10 \\
\hline \multirow{8}{*}{ РФ-2-18 } & $0-0,5$ & 6,8 & 0,47 & & не опр & \\
\hline & $0,5-5$ & 6,8 & - & 1,27 & 0,842 & - \\
\hline & $5-15$ & 5,9 & 0,47 & 1,03 & 0,280 & 9 \\
\hline & $15-25$ & 5,6 & 0,56 & 0,87 & 0,189 & 9 \\
\hline & $25-40$ & 5,7 & - & 0,79 & 0,316 & 7 \\
\hline & $45-59$ & 6,4 & - & 0,58 & 0,354 & 6 \\
\hline & $59-65$ & 8,1 & - & 1,44 & 0,734 & 7 \\
\hline & $75-85$ & 9,1 & 0,09 & 0,91 & 0,500 & 7 \\
\hline \multirow{11}{*}{ РФ-2-30 } & $0-4(5)$ & 6,5 & - & 11,61 & 0,330 & 13 \\
\hline & $4(5)-10(12)$ & 8,6 & - & 2,70 & 0,222 & 10 \\
\hline & $10(12)-26(31)$ & 9,0 & 0,84 & 1,78 & 0,530 & 15 \\
\hline & $26(31)-39(46)$ & 8,7 & 2,25 & 1,60 & 1,838 & 36 \\
\hline & $36(46)-56(72)$ & 8,3 & 0,37 & 0,72 & 0,542 & 13 \\
\hline & $66(70)-75$ & 8,3 & 0,47 & 1,29 & 0,292 & 10 \\
\hline & $70-100$ & 7,4 & & 0,17 & 0,048 & 6 \\
\hline & $120-150$ & 7,1 & - & 0,17 & 0,064 & 5 \\
\hline & $160-180$ & 7,1 & - & 0,16 & 0,012 & 3 \\
\hline & $210-230$ & 7,6 & - & 0,10 & 1,984 & 6 \\
\hline & $230-270$ & 7,5 & - & 0,10 & 0,010 & 4 \\
\hline
\end{tabular}

Примечание: «не опр.» — не определяли; «-»—-не обнаружено. 
Самые низкие значения $\mathrm{aF}$ отмечены в почвах с кислой реакцией среды (РФ2-11, РФ-2-13, РФ-2-16), приуроченные к местам, примыкающим непосредственно к Кучигерскому болотному массиву с активно разгружающимися грифонами (рис. 2). По мере удаления от болота показатель активности фтора в почвах постепенно увеличивается (РФ-2-18, РФ-2-20, РФ-2-21). Наибольшая активность ионов фтора отмечается в поверхностной солевой корке. Контрастное распределение $\mathrm{aF}$ имеют почвы, расположенные на приподнятой аллювиальной равнине около p. Индэхэн (РФ-2-24, РФ-2-28, РФ-2-30). В этих почвах проявляется тенденция к увеличению $\mathrm{aF}$ (рис. 2).
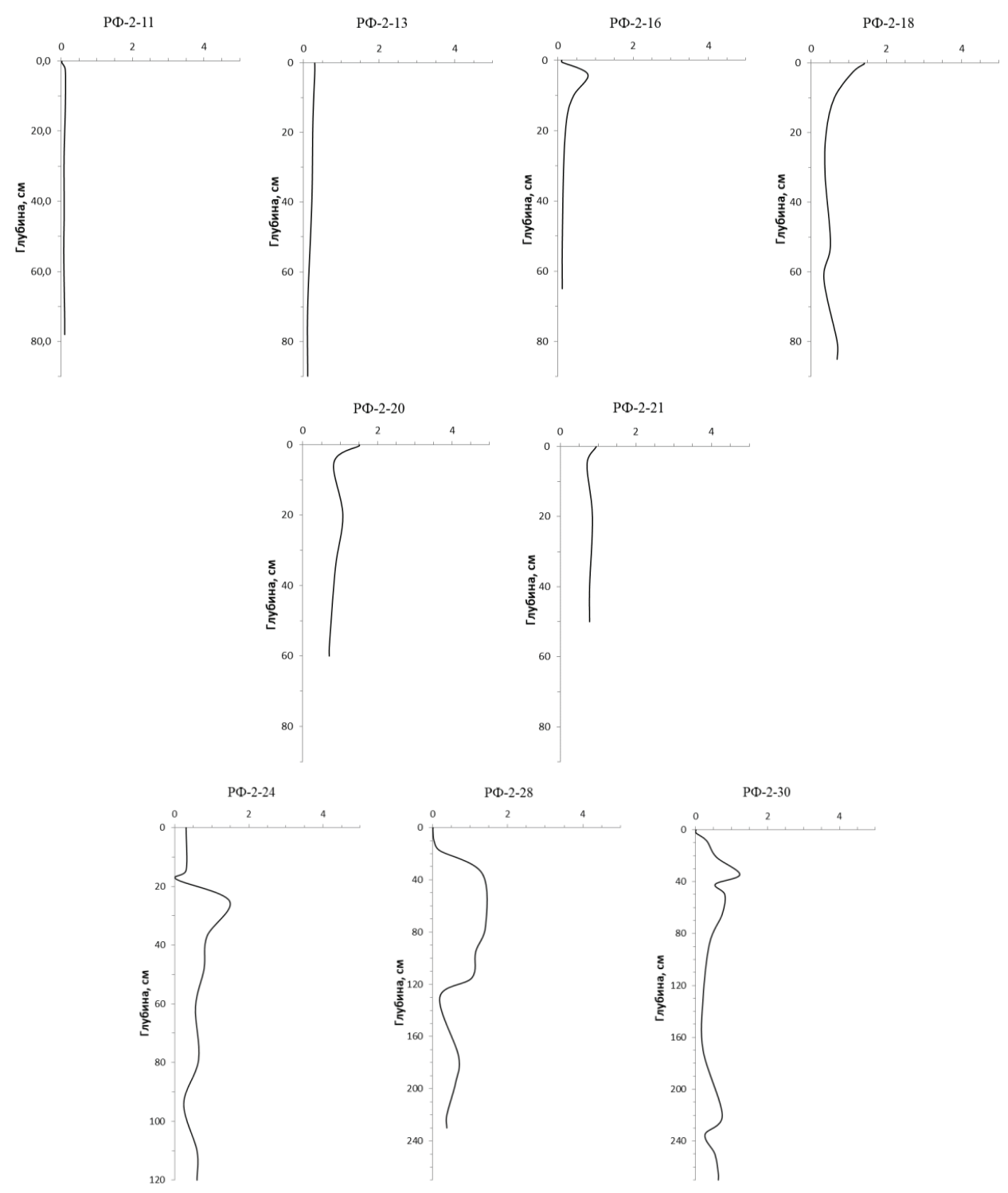

Рис. 2. Профильное распределение активности фтора с $\mathrm{aF}=0,01-2$ ммоль/л 
Вторая группа почв характеризуется активностью фтора в диапазоне доверительного интервала 1,30-1,84 ммоль/л, среднее значение которого составляет $\mathrm{aF}=1,57$ ммоль/л. Эти почвы имеют разную степень засоления и характеризуются более высокими значениями реакции среды. Засоленные почвы в основном имеют легкий гранулометрический состав, содержание гумуса низкое (табл. 3).

Таблииа 3

Некоторые физико-химические свойства почв с средней активность фтора

\begin{tabular}{|c|c|c|c|c|c|c|}
\hline \multirow[t]{2}{*}{ Разрезы } & \multirow[t]{2}{*}{ Глубина } & \multirow[t]{2}{*}{$\mathrm{pH}_{\text {водн }}$} & $\mathrm{CO}_{2}$ & Гумус & $\begin{array}{l}\text { Сухой } \\
\text { остаток }\end{array}$ & $\begin{array}{c}\text { Сод. } \\
\text { фракции } \\
<0,01\end{array}$ \\
\hline & & & \multicolumn{4}{|c|}{$\%$} \\
\hline \multirow{6}{*}{ РФ-2-19 } & Солевая корка & 9,1 & \multirow{2}{*}{\multicolumn{4}{|c|}{ не опр. }} \\
\hline & $0,5-4$ & 8,4 & & & & \\
\hline & $4-9$ & 8,0 & - & 0,77 & - & не опр. \\
\hline & $9-20$ & 6,6 & - & 0,98 & 0,484 & 8 \\
\hline & $22-30$ & 6,4 & - & 1,67 & 0,638 & 14 \\
\hline & $30-50$ & 8,0 & - & 1,39 & 0,614 & 10 \\
\hline \multirow{8}{*}{ РФ-2-29 } & $10-20$ & 7,9 & 0,28 & 11,70 & 0,410 & 14 \\
\hline & $26-40$ & 8,6 & 1,03 & 5,96 & 0,522 & 19 \\
\hline & $40-60$ & 8,8 & 3,38 & 1,22 & 0,364 & 22 \\
\hline & $70-80$ & 8,5 & 1,40 & 2,88 & 0,738 & 24 \\
\hline & $80-90$ & 8,1 & 0,37 & 5,25 & 0,312 & 52 \\
\hline & $90-120$ & 8,2 & 0,75 & 2,82 & 0,226 & 25 \\
\hline & $130-180$ & 8,5 & 0,93 & 0,53 & 0,344 & 6 \\
\hline & $180-230$ & 8,7 & 1,78 & 0,50 & 0,300 & 4 \\
\hline \multirow{15}{*}{ РФ-2-31 } & $0-2$ & 6,3 & - & 0,77 & 0,104 & 6 \\
\hline & $2-22$ & 7,1 & 0,09 & 0,31 & 0,060 & 5 \\
\hline & $27-41$ & 7,9 & 0,47 & 1,13 & 0,148 & 19 \\
\hline & $41-66$ & 8,1 & 1,50 & 3,34 & 0,154 & 17 \\
\hline & $66-75$ & 8,3 & 0,09 & 0,43 & 0,090 & 12 \\
\hline & $90-120$ & 8,3 & 2,53 & 0,40 & 0,068 & 10 \\
\hline & $130-140$ & 8,4 & 1,31 & 0,27 & 0,064 & 4 \\
\hline & $150-160$ & 8,3 & 2,72 & 0,38 & 0,122 & 10 \\
\hline & $160-180$ & 8,6 & 1,31 & 0,29 & 2,422 & 5 \\
\hline & 190-220 & 9,0 & 2,25 & 0,18 & 2,066 & 4 \\
\hline & $220-260$ & 8,8 & 2,44 & 0,21 & 0,078 & 3 \\
\hline & $260-290$ & 8,2 & 0,75 & 0,20 & 1,748 & 7 \\
\hline & $290-310$ & 7,4 & 0,09 & 0,20 & 0,124 & 5 \\
\hline & $310-320$ & 8,3 & 0,09 & 0,19 & 0,488 & 4 \\
\hline & $320-340$ & 8,9 & 0,09 & 0,15 & 2,372 & 13 \\
\hline
\end{tabular}

Примечание: см. табл. 2. 
В профиле почвы активность фтора резко меняется (рис. 3). Распределение по профилю схоже с почвами первой группы. Самые высокие значения активности приурочены к верхним горизонтам с солевой коркой (РФ-2-19 и РФ-2-23). В ряде почвенных разрезов (РФ-2-14, РФ-2-17, РФ-2-19, РФ-2-23) накопление F происходит на глубинах 10-20 см, здесь зафиксированы максимальные пики aF, ниже происходит резкое уменьшение.

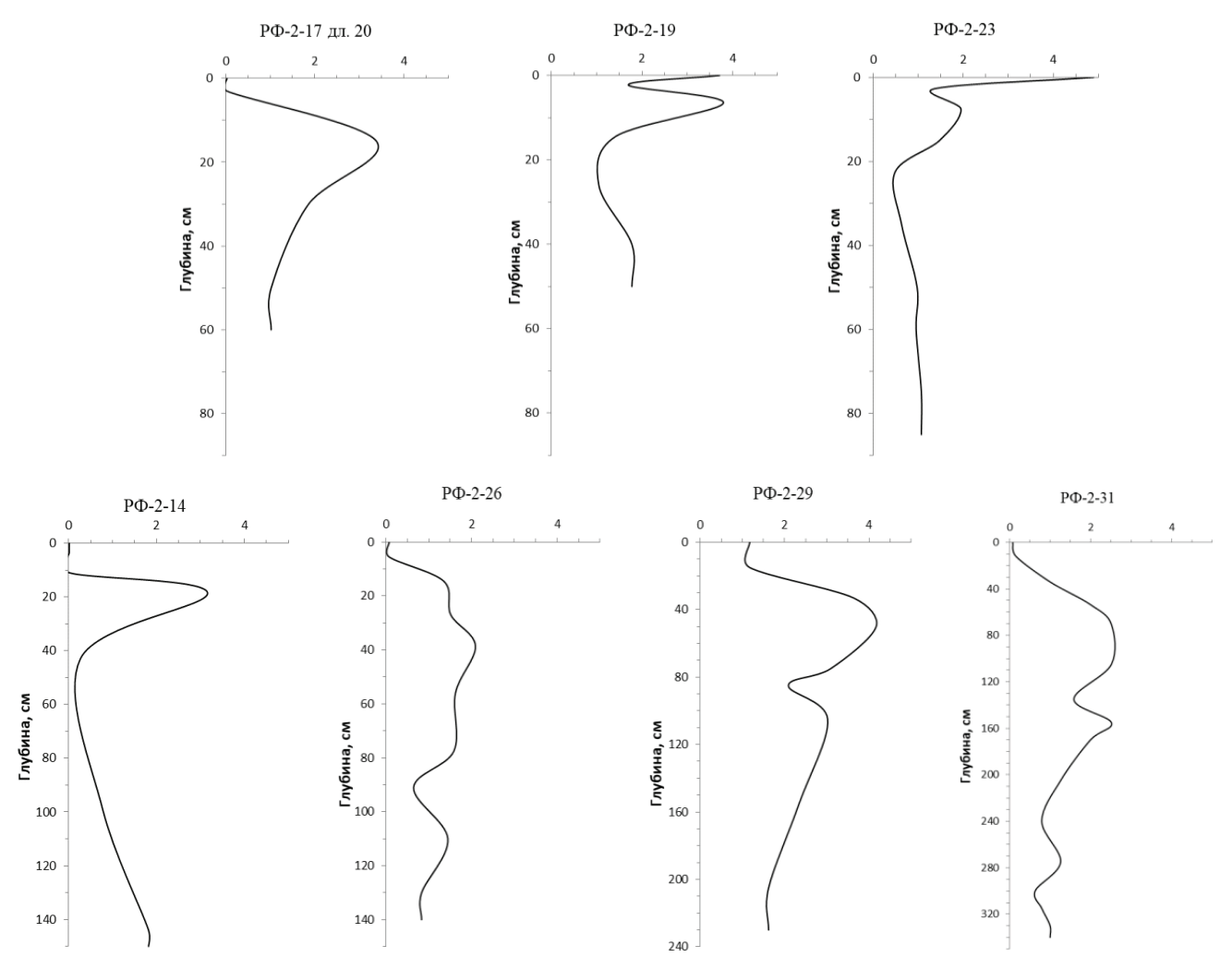

Рис. 3. Профильное распределение активности фтора с $\mathrm{aF}=2,0-5,0$ ммоль/л

В разрезах, в которых производилось глубокое бурение (РФ-2-14, РФ-2-26, РФ-2-29, РФ-2-31), значение aF сильно варьирует по профилю и имеет несколько пиков: в верхних слоях - 20-80 см, нижних - 120-140 (160) см, а в РФ-2-31 280 см. В этих горизонтах наблюдается увеличением фракции физической глины, которая при щелочных условиях способствует адсорбции ионов фтора.

Из всей выборки выделяются сильно засоленные участки (РФ-2-15 и РФ-2-25) с аномально высоким показателем активности фтора. В этих почвах наблюдается очень большой разброс $\mathrm{aF}$ - от 0,08 до 112,2 ммоль/л, т. е. разница в показателях активности более чем в 1000 раз. В связи с таким положением для данной группы среднее значение не вычислялось. Эти почвы имеют очень сильное поверхностное засоление, содержание гумуса низкое (табл. 4). 
Таблицча 4

Некоторые физико-химические свойства почв с аномально высокой активностью фтора

\begin{tabular}{|c|c|c|c|c|c|c|}
\hline \multirow[t]{2}{*}{ Разрезы } & \multirow[t]{2}{*}{ Глубина } & \multirow[t]{2}{*}{$\mathrm{pH}_{\text {водн }}$} & $\mathrm{CO}_{2}$ & Гумус & $\begin{array}{c}\text { Сухой } \\
\text { остаток }\end{array}$ & $\begin{array}{c}\text { Сод. фракции } \\
<0,01\end{array}$ \\
\hline & & & \multicolumn{4}{|c|}{$\%$} \\
\hline \multirow{7}{*}{ РФ-2-15 } & Солевая корка & 9,5 & 0,28 & не опр. & 9,090 & не опр. \\
\hline & $0-10$ & 9,1 & - & 0,32 & 0,140 & 6 \\
\hline & $10-30$ & 8,3 & - & 0,27 & 0,090 & 6 \\
\hline & $30-50$ & 7,9 & - & 0,31 & 0,124 & 10 \\
\hline & $50-97$ & 6,6 & - & 0,32 & 0,088 & 7 \\
\hline & $97-120$ & 5,4 & - & 1,77 & 0,882 & 12 \\
\hline & $125-140$ & 7,2 & - & 0,89 & 1,086 & 8 \\
\hline \multirow{7}{*}{ РФ-2-25 } & Солевая корка & 9,7 & - & 0,98 & 17,362 & не опр. \\
\hline & $0-5$ & 9,6 & - & 0,65 & 3,020 & 15 \\
\hline & $5-24$ & 9,2 & 0,47 & 0,98 & 0,286 & 16 \\
\hline & $24-30$ & 9,1 & 0,37 & 0,39 & 0,154 & 10 \\
\hline & $30-43$ & 8,9 & 0,37 & 0,36 & 0,128 & 10 \\
\hline & $43-64$ & 8,6 & - & 0,32 & 0,108 & 6 \\
\hline & $64-66$ & 8,3 & 0,09 & 0,36 & 0,144 & 5 \\
\hline
\end{tabular}

Эти участки выделяются из общего фона отсутствием какой-либо растительности. Такое явление объясняется токсичным действием повышенного содержания фтора для растений, так как в солевых корках РФ-2-15 и РФ-2-25 зафиксированы аномально высокие значения равные 75,9 и 112,2 ммоль/л соответственно (рис. 4).
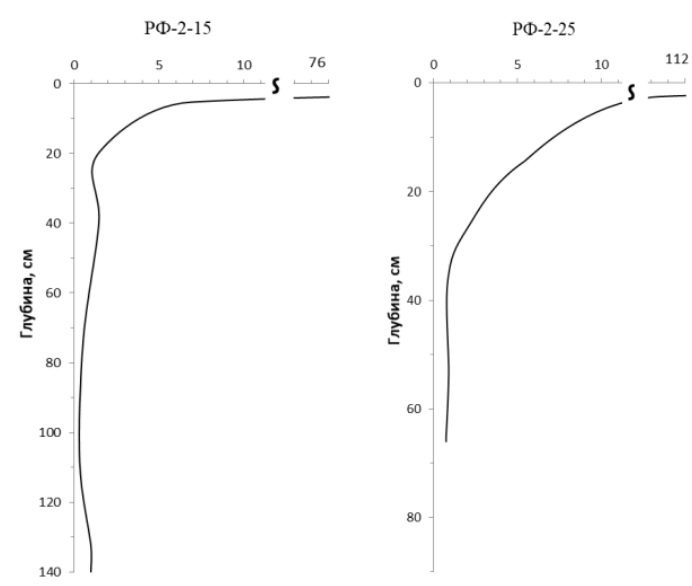

Рuc. 4. Профильное распределение активности фтора с аномальными значениями $\mathrm{aF}$ ммлоль/л 
Наличие в Улюнханской впадине участков с аномально высокой активностью фтора может быть индикатором активной тектонической деятельности земной коры, которая сопровождается газогидротермальными проявлениями пульсирующего характера.

Изученные засоленные почвы по активности фтора (aF) условно можно разделить на три группы. К первой группе отнесены почвы с низкой активностью (0,01-2,0 ммоль/л), ко второй - со средней (2,0 до 5,0 ммоль/л), третья группа имеет аномально высокую активность (до 112 ммоль/л). Самые низкие значения имеют почвы болотных массивов, по мере удаления разрезов от болота и увеличением кислотности раствора прослеживается тенденция увеличения aF. Такая закономерность может быть связана с щелочным и сорбционным барьером, на котором оседают ионы F, для сильнозасоленных почв ярко выражен испарительный барьер в виде солевой корки.

\section{Заключение}

На данном этапе исследования установлено, что в почвах зон разгрузки кучигерских гидротерм характерна различная активность фтора. Условно выделено три группы почв с разной степенью активности F: почвы с низкой активностью, средней и аномально высокой. Почвы с относительно одинаковой активностью могут находится на разных геоморфологических позициях и, наоборот, почвы с разными значениями активности находятся очень близко друг от друга. Таким образом можно утверждать, что активность фтора не зависит от геоморфологической сопряженности. Для данных почв имеет место пульсирующий характер поступления фтора в почву. Такая ситуация может быть объяснена разломной активной тектонической деятельности территории, при которой через вновь образованные разломы и трещины происходят интенсивное поступление различных элементов вместе с минеральными водами, грязью и газами.

Работа выполнена при финансовой поддержке гранта РФФИ № 18-04-00454 А.

\section{Литература}

Авцын А. П., Жаворонков А. А., Риш М. А., Строчкова Л. С Микроэлементозы человека: этиология, классификация, органопатология. М.: Медицина, 1991. 496 с.

Агрохимические методы исследования почв. М.: Наука, 1975. 656 с.

Аничкина Н. В. Исследования биогеохимии фтора в компонентах геосистем // Научное обозрение. Биологические науки. 2016. № 3. С. 23.

Аринушкина Е. В. Руководство по химическому анализу почв. М.: Изд-во МГУ, 1970. $487 \mathrm{c}$.

В Бурятии зарегистрировано землетрясение [Электронный ресурc]. URL: http://03. mchs.gov.ru/pressroom/news/item/8379427 (дата обращения: 26.09.2019).

Жамбалова А. Д. Засоленные почвы зон разломов Кучигерских гидротерм и их геохимические особенности: автореф. дис. ... канд. биол. наук. Улан-Удэ, 2018. 22 с.

Замана Л. В. Фтор в азотных термах Забайкалья // Геология и геофизика. 2000. Т. 41 (11). C. $1575-1581$.

Засоленные почвы России / отв. ред. Л. Л. Шишов, Е. И. Панкова. М.: Академкнига, 2006. $544 \mathrm{c}$.

Касимов Н. С. Геохимия ландшафтов зон разломов (на примере Казахстана). М.: Изд-во Моск. ун-та, 1980. 119 с. 
Кашин В. К., Афанасьева Л. В., Убугунов Л. Л. Фтор в компонентах ландшафтов Западного Забайкалья // Агрохимия. № 10. 2015. С. 38-49.

Классификация и диагностика почв России. Смоленск: Ойкумена, 2004. 342 с.

Конарбаева Г. А. Галогены в почвах юга Западной Сибири. Новосибирск: Изд-во СО PAH, 2004. 200 c.

Лунина О. В., Гладков А. С., Шерстянкин П. П. Новая электронная карта активных разломов юга Восточной Сибири // ДАН. 2010. Т. 433, № 5. С. 662-667.

Лысак С. В. Тепловой поток в зонах активных разломов на юге Восточной Сибири // Геология и геофизика. 2002. Т. 43. №8. С. 791-803.

Перельман А. И., Касимов Н. С. Геохимия ландшафта. М.: Изд-во МГУ, 1999. 610 с.

Плюснин А. М., Замана Л. В., Шварцев С. Л., Токаренко, М. К. Чернявский Гидрохимические особенности состава азотных терм Байкальской рифтовой зоны // Геология и геофизика. 2013. № 5. С. 647-664.

Полевой определитель почв России. М.: Почвенный ин-т им. В. В. Докучаева, 2008. 182 с.

СанПиН 2.1.4.1116-02 Питьевая вода. Гигиенические требования к качеству воды, расфасованной в емкости. Контроль качества (с изменениями от 25 февраля 2010 г., 28 июня 2010 г.). Минздрав России. М., 2002.

Убугунов В. Л., Хитров Н. Б., Убугунова В. И., Жамбалова А. Д., Рупышев Ю. А., Аюшина Т. А., Парамонова А. Е., Цыремпилов Э. Г., Насатуева Ц. Н. Эндогенный фактор и морфогенетическое строение почв в зоне влияния Кучигерских гидротерм (Байкальская рифтовая зона, север Баргузинской котловины) // Природа внутренней Азии. Nature of Inner Asia. 2018. № 4(9). C. 54-72.

Фомин Г. С., Фомин А. Г. Почва. Контроль качества и экологической безопасности по международным стандартам. М.: Протектор, 2001. 304 с.

Хитров Н. Б. Руководство по лабораторным методам исследования ионно-солевого состава нейтральных и щелочных минеральных почв. М.: Почвенный институт им. Докучаева, 1990. 235 с.

Чернявский М. К., Плюснин А. М., Дорошкевич С. Г., Будаев Р. Ц. Рекреационно-бальнеологические особенности северо-восточной части Баргузинской котловины // География и природные ресурсы. 2018. № 2. С. 63-72.

Шварцев С. Л. Механизмы концентрации фтора в азотных термах // Известия Томского политехнического ун-та. 2017. № 12. С. 105-115.

Школьник М. Я. Микроэлементы в жизни растений. Л.: Наука, 1974. С. 226-229.

Kabata-Pendias A. Trace Elements in Sols and Plants. 4th Ed. Taylor and Francis Group, LLC, 2011. $505 \mathrm{p}$.

\section{FLUORINE IN WATERS AND SOILS OF THE ULYUNKHAN DEPRESSION (BAIKAL RIFT ZONE)}

\section{A. D. Zhambalova}

\section{Anna D. Zhambalova}

Cand. Sci. (Biol.),

Institute for General and Experimental Biology SB RAS

6 Sakhyanovoy St., Ulan-Ude 670047, Russia

E-mail: zhambalova_ann@mail.ru 
The article presentes primary data on fluorine activity in saline soils of the Ulyunkhan Depression's tectonic fault zones (northwestern part of the Barguzin Basin). It has been revealed that the activity of fluorine ions varies in a very wide range from 0.02 to $112.20 \mathrm{mmol} / \mathrm{L}$. The high activity of F ions is mainly represented at the evaporation barrier. Abnormally high rates are observed in the surface salt crusts. Fluorine activity inside the soil profile depends on the reaction of the media. The lowest values of aF are confined to the soils of wetland with acid reaction. aF increase in soils of alluvial elevation arises in horizons with more alkaline conditions. The fluorine ions are introduced due to the latent intra-profile gas-hydrothermal activity of the Kuchiger springs, which is carried out through tectonic cracks and faults and has a pulsating character.

Keywords: Barguzin Basin; saline soils; fluorine activity; soils of fault zones; geochemical barrier. 